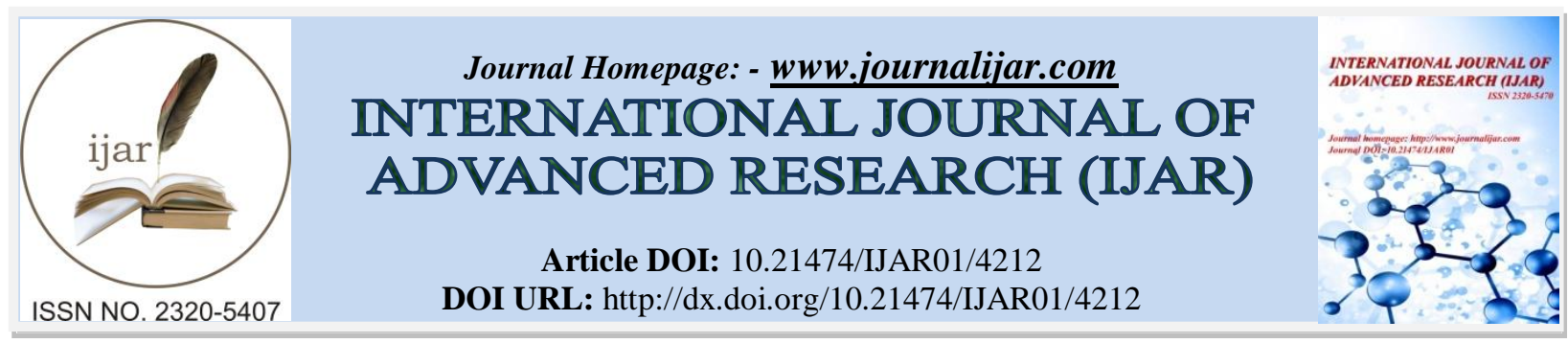

RESEARCH ARTICLE

\title{
A STUDY OF EMPOWERMENT AMONG ADOLESCENT GIRLS IN RELATION TO THEIR SCHOOL ENVIRONMENT.
}

Dr. Amardeep Kaur.

Associate Professor, Babe Ke College of Education, Mudki,Ferozepur, Punjab.

\section{Manuscript Info}

Manuscript History

Received: 19 March 2017

Final Accepted: 17 April 2017

Published: May 2017

Key words:-

Empowerment, Adolescent girls, School Environment.

\section{Abstract}

The present study is designed to investigate Empowerment among adolescent girls in relation to their School Environment. Descriptive method is used in this study. The sample comprises 200 adolescent girls selected randomly from Sri Muktsar Sahib District. Adolescent Girls' Empowerment Scale by Dr. Devendra Singh Sisodia and Dr. Alpana Singh and School Environment Inventory by Dr. Karuna Shanker Misra were used to collect data. The statistical techniques used in the study were Coefficient of correlation to find out the relationship between Empowerment and School Environment of adolescent girls and T-test to find the significance of difference between rural and urban adolescent girls in relation to Empowerment. The major findings reveal no significant relationship between Empowerment and School Environment of Rural and Urban Adolescent girls; also no significant difference was found between the Empowerment level of Rural and Urban Adolescent girls.

Copy Right, IJAR, 2017,. All rights reserved.

\section{Introduction:-}

For centuries women have been treated as weak, obedient, shy and timid partner of men and thereby have enjoyed an inferior status in society. It is the growth in education and vocational opportunities that women throughout the world are becoming more conscious of their rights. School environment being the basis for growth and development of a healthy adolescent girl plays a vital role here.

\section{Empowerment among Adolescent girls:-}

Empowerment refers to enabling people to take charge of their own life. For women, empowerment emphasizes the importance of increasing their power and taking control over decisions and issues that shape their lives.

The empowerment of adolescent girls is indispensable if the countries of the region are to achieve the millennium development goals. Effects toward this end should be made on various fronts and should aim at co-ordinate actions that have lasting and substantial effects on the health and well being of this population, which is very diverse yet uniform with respect to its vulnerability.

Women's empowerment addresses power and relationship in society intertwined with gender, class, race, ethnicity, age, culture and history. Power is identified with equity and equality for women and men in access to resources, participation in decision-making and control over distribution of resources and benefits. Gender equality is 
addressed at these different levels with the aim of increasing equality between men and women, and achieving women's empowerment.

Access to resources refers to both the means and the right to obtain services, products or commodities. Gender gaps in access to resources and services are a major obstacle to women's development. The process of empowerment includes mobilizing women to eliminate these gaps. A cornerstone of gender equality is women's equal participation in decision making. To empower women literally speaking, is to give power to women, 'Power' here does not mean a mode of domination over others, but a sense of internal strength and confidence to face life, the right to determine one's choices in life, the ability to influence the social processes that affects one's life, an influence in the direction of social change, a share in decision making and capacity building to contribute towards national development.

Empowerment is the expansion of assets and capabilities of women to participate in, negotiate with, influence, control, and hold accountable institutions that affect their lives.

Empowering women requires the removal of formal and informal institutional barriers that prevent them from taking action to improve their well being individually or collectively and limit their choices. The key formal institutions include the laws, rules and regulations upheld by states, markets, civil society and international agencies; informal institutions include norms of social solidarity, social exclusion and corruption among others.

The process of women's empowerment begins in the mind, by changing women's consciousness. Empowerment is an active, multidimensional process, which enables women to realize their full identity and potential in all spheres of life. Power is not a commodity to be transacted nor can it be given away as alms. Power has to be acquired and once acquired, it needs to be exercised, sustained and preserved. Women's empowerment can be viewed as a continuum of several inter related and mutually reinforcing components.

Women need to be empowered for gaining collective strength because when we are discussing the role of women, we are talking of changing the equilibrium of social forces to treat them as equal partners in the society and to bring recognition to all their roles.

Empowerment of women means many things according to Kamala Basin (1992):

* It means recognizing women's contribution and women's knowledge.

* It means helping women fight their own fears and feelings of inadequacy and inferiority.

* It means women enhancing their self independence and self reliance.

* It means women controlling resources like land and property.

* It means reducing women's burden of work, especially at home.

* It means creating and strengthening women's group and organization.

* It means promoting qualities of nurturing, caring and gentleness.

Women's empowerment allows women to be appreciated and acknowledged for who they are and what they do. It is not particularly the ideology of feminism that empowers women, but rather their capacities to face bravely the individual and social facts of their actual situations (Lengermann and Wallace, 1985).

The female empowerment approach stresses the capacity of women to increase their self-reliance and internal strength. The empowerment approach to women's advancement in developing countries recognizes that the patriarchal structure of subordination must be addressed through women's organization at the grass root level. Such local group can facilitate bottom-up change by providing a social mechanism to raise women's consciousness about their subordination. Becoming aware of women's position in society, and transferring skills to enable women to gain access to education, employment and health care are key components in many women empowerment programmes today.

\section{School Environment:-}

Human beings are always immersed in a social environment which not only changes the very structure of the individual or just compels him to recognize facts but also provides him with a readymade system of signs. It imposes on him a series of obligations. Two environments home and school share an influential space in a child's life and there exists a unique juxtaposition between the two . By its very nature, the family is the social-biological unit that exerts the greatest influence on the development and perpetuation of the individual's behaviour. Next to family, the school is the most important experience in the process of child development. When the child enters the 
school arena, he or she is presented with new opportunities in terms of socialization and cognitive development. These opportunities are provided in different measures in different schools and may have a direct impact on the cognitive and affective behaviour of students. The nature of this impact can be understood if we devote our research energies to find out the environmental variables that are most effective in promoting optimum development of each child's potentialities.

School Environment may be defined as the qualities of a school that affects the attitude, behaviour and achievement of the individual. School environment is the sum of all physical, social, emotional and mental factors that contribute to the total teaching learning situations. School environment has a very important role to import right type of education to the children. It may be defined as a set of properties of the work environment that are specific to a particular organization.

The good school environment produces good students. If the school environment is not according to the child's needs, he does not adjust with the school environment. If in the school the child does not get the proper guidance, teacher's help and library facilities, then education due to these reasons will not provide all round development of the child.

Good (1945) says, "School environment refers to the environment as perceived by as aggregate of all the psychological and social conditions that determine the mental, social, emotional, intellectual growth and development of child."

C.V Good (1959) opines, "The school environment refers to the environment as perceived by the students and as is measured on the environment scale."

Sweeney (1988) states, "School climate is a term used to describe how pupils feel about their school."

Lindelow (1989) says, "School climate may be defined as the feelings an individual experiences within a school system."

School environment offers wonderful laboratory for development of good human relations, democratic methods, responsibility, self-confidence and other essential to happy and purposeful life. It depends upon administrative officers, teachers, custodian and administrative officers, teachers, custodian and other staff members.

\section{Operational Definitions:-}

\section{Empowerment Among Adolescent Girls:-}

Empowerment among adolescent girls in the present study refers to the empowerment of adolescent girls pertaining to power and entitlements, autonomy and self reliance, participation, capacity building, social, political and legal awareness and exposure to information media.

\section{School Environment:-}

School Environment in the present study refers to the psycho-social climate of schools as perceived by the pupils. It is the quality and quantity of the cognitive, emotional and social support that has been available to the students during their school life in terms of teacher-pupil interactions.

\section{Need and Significance of the Study:-}

Empowerment and school environment are interlinked. Both these aspects play vital role in an adolescent's life. There is need to know the relation among empowerment and school environment. This study was undertaken to analyze the current status of school environment and empowerment level of adolescent girls with an aim to create awareness among girls and their parents to make them enjoy equal status as their male counter parts for their holistic development.

\section{Objectives of the Study:-}

- To find out the Empowerment level of Adolescent girls.

- To study the relationship between Empowerment among Adolescent girls and School Environment.

- To compare the Empowerment level of Rural and Urban Adolescent girls. 


\section{Delimitations of the Study:-}

- Adolescent girls from schools of District Sri Muktsar Sahib were taken for the study.

- The study was limited to Adolescent girls only.

- The present study was delimited to study the Empowerment of Adolescent girls in relation to School Environment.

\section{Review of related literature:-}

Craeynest, M. (2009) found that increased availability of extra co-curricular activities and supervision in school are related to greater participation in extra co-curricular activities among adolescent boys and girls. Sindhuja and V. Sreedevi (2011) observed that both external and internal factors play an active role in women's empowerment. Vivek Dalela and Sarfaraz Ahmad (2012) found that there is no significant difference in academic achievement of adolescents between satisfied and dissatisfied groups with their school environment. Anita Joshi (2012) found a significant difference between literate women residing in NGO non -covered areas in different dimensions of empowerment life confidence level, health awareness and political awareness. R.R. Mandankar (2013) found that school environment has significant negative direct effect on academic achievement of urban and rural students. Marami Goswami (2013) through her study leads our attention to the direction that women empowerment is a multidimensional process and it is related with different factors viz. personal autonomy, family decision making, domestic economic decision and political autonomy. Veenu Khurana and Neeraj Gohlan (2013) reported that empowerment of adolescent girls and their socio-economic status have high correlation and they are significantly correlated. Rachna Sharma (2014) revealed that the self concept and empowerment level of urban adolescent girls were higher than the rural adolescent girls. Aruna Anand \& Malkeet Kaur (2015) through their study revealed that there is a positive and significant interactional effect of leadership effectiveness and school environment on school satisfaction of adolescents. Charanjit Kaur \& Nidhi Chandna (2015) found that achievement motivation is affected by school environment and is higher in boys as compared to girls and even in smart school students as compared to conventional schools. Smart schools provide students with better school environment as compared to conventional schools. Syeda Mubina Khatoon \& L.N. Konwar (2016) indicated a positive significant relationship between school climate and academic achievement.

\section{Hypotheses:-}

1. There is no significant difference between the Empowerment level of Rural and Urban Adolescent girls.

2. There is no significant relationship between Empowerment and School Environment of Rural Adolescent girls.

3. There is no significant relationship between Empowerment and School Environment of Urban Adolescent girls.

\section{Method and Procedure:-}

The present study is a descriptive survey. The sample comprises 200 adolescent girls selected randomly from Sri Muktsar Sahib District. Adolescent Girls' Empowerment Scale by Dr. Devendra Singh Sisodia and Dr. Alpana Singh and School Environment Inventory by Dr. Karuna Shanker Misra were used to collect data.

The statistical techniques used in the study were Mean, Standard Deviation to study the nature of distribution of scores;Coefficient of correlation to find out the relationship between Empowerment and School Environment of adolescent girls and T-test to find the significance of difference between rural and urban adolescent girls in relation to Empowerment.

\section{Analysis:-}

Objective 1: To find out the Empowerment level of Adolescent girls.

Table 1:- Showing the Mean and Standard Deviation score of the Empowerment among Adolescent girls.

Empowerment among Adolescent girls

\begin{tabular}{|l|l|l|}
\hline Mean & Standard Deviation & Interpretation \\
\hline 183.48 & 17.36 & High Empowerment Level \\
\hline
\end{tabular}

Table 1 shows the Mean value of Empowerment among adolescent girls which is 183.48. Therefore, the adolescent girls have high empowerment level. 
Table 2:- Showing the Frequency Distribution of Empowerment level of Adolescent girls.

\begin{tabular}{|l|l|l|l|}
\hline Empowerment among Adolescent girls & \\
\hline Categories & Frequency & Cumulative frequency & Percentage \\
\hline High & 181 & 200 & 90.5 \\
\hline Average & 19 & 19 & 9.5 \\
\hline Low & 0 & 0 & 0 \\
\hline
\end{tabular}

Table 2 shows the Frequency Distribution and percentage of adolescent girls, according to their level of Empowerment. The level of Empowerment is divided into three categories; High, Average and Low. Out of 200 adolescent girls, 181 adolescent girls fall in high level of empowerment which holds the $90.5 \%$ of total sample. Remaining, 19 adolescent girls fall in average level of empowerment which holds $9.5 \%$ of total sample.

Objective 2: To Study the relationship between Empowerment among Adolescent girls and School Environment.

Table 3:- Showing the value of Coefficient Correlation between Empowerment and School Environment of Rural Adolescent girls.

\begin{tabular}{|c|c|c|c|c|c|c|c|}
\hline Tools & \multicolumn{7}{|c|}{ SCHOOL ENVIORNMENT } \\
\hline \multirow{3}{*}{ 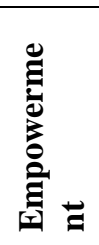 } & $\begin{array}{l}\text { Categories/ } \\
\text { Dimensions }\end{array}$ & $\begin{array}{l}\text { Creative } \\
\text { Stimulation }\end{array}$ & $\begin{array}{l}\text { Cognitive } \\
\text { Encouragement }\end{array}$ & Acceptance & Permissiveness & Rejection & Control \\
\hline & $\begin{array}{l}\text { All } \\
\text { Adolescent } \\
\text { Girls }\end{array}$ & 0.08 & 0.01 & 0.12 & 0.04 & 0.02 & $0.24 * *$ \\
\hline & Rural & -0.01 & 0.06 & 0.09 & -0.02 & -0.10 & $0.19^{*}$ \\
\hline
\end{tabular}

*Significant at 0.05 level of confidence.

**Significant at both levels of confidence ( 0.05 and 0.01$)$.

Table 3 shows that value of co-efficient correlation ' $r$ ' between Empowerment among rural adolescent girls and School Environment dimension of Creative Stimulation is - -0.01 . The Table Value at 0.05 level is 0.19 and 0.01 level is 0.25 . The calculated value is less than table value at both levels which means it is not significant at both levels. Value of co-efficient correlation ' $r$ ' between Empowerment among rural adolescent girls and School Environment dimension of Cognitive Encouragement is 0.06 . The Table Value at 0.05 level is 0.19 and 0.01 level is 0.25.The calculated value is less than table value at both levels which means it is not significant at both levels. Value of coefficient correlation ' $r$ ' between Empowerment among rural adolescent girls and School Environment dimension of Acceptance is 0.09 . The Table Value at 0.05 level is 0.19 and at 0.01 level is 0.25 . The calculated value is less than table value at both levels which means it is not significant at both levels. Value of co-efficient correlation ' $r$ ' between Empowerment among rural adolescent girls and School Environment dimension of permissiveness is - 0.02 . The Table Value at 0.05 level is 0.19 and at 0.01 level is 0.25 . The calculated value is less than table value at both levels which means it is not significant at both levels. Value of co-efficient correlation ' $r$ ' between Empowerment among rural adolescent girls and School Environment dimension of Rejection is -0.10 . The Table Value at 0.05 level is 0.19 and at 0.01 level is 0.25 . The calculated value is less than table value at both levels which means it is not significant at both levels. Value of co-efficient correlation ' $r$ ' between Empowerment among rural adolescent girls and School Environment dimension of Control is 0.19. The Table Value at 0.05 level is 0.19 and at 0.01 level is 0.25 . The calculated value is equal than table value at 0.05 level and less than the table value at 0.01 level which means it is significant at 0.05 level and not significant at 0.01 level.

From the above result it is clear that obtained value of co-efficient of correlation is not significant at both 0.05 and 0.01 levels.

Therefore the hypothesis no.2 "There is no significant relationship between Empowerment and School Environment of Rural Adolescent girls" is accepted.

Table 4:- Showing the value of Co-efficient Correlation between Empowerment and School Environment of Urban Adolescent girls.

\begin{tabular}{|c|c|c|c|c|c|c|c|}
\hline Tools & \multicolumn{7}{|c|}{ SCHOOL ENVIORNMENT } \\
\hline 되 $\Xi$ & $\begin{array}{l}\text { Categories/ } \\
\text { Dimensions }\end{array}$ & $\begin{array}{l}\text { Creative } \\
\text { Stimulation }\end{array}$ & $\begin{array}{l}\text { Cognitive } \\
\text { Encouragement }\end{array}$ & Acceptance & Permissiveness & Rejection & Control \\
\hline
\end{tabular}




\begin{tabular}{|l|l|l|l|l|l|l|l|}
\hline & $\begin{array}{l}\text { All } \\
\text { Adolescent } \\
\text { Girls }\end{array}$ & 0.08 & 0.01 & 0.12 & 0.04 & 0.02 & $0.24 * *$ \\
\cline { 2 - 7 } & Urban & 0.18 & -0.07 & 0.14 & 0.09 & 0.01 & $0.30 * *$ \\
\hline
\end{tabular}

Table 4 shows that value of co-efficient correlation ' $r$ ' between Empowerment among urban adolescent girls and School Environment dimension of Creative Stimulation is 0.18. The Table Value at 0.05 level is 0.19 and at 0.01 level is 0.25 . The calculated value is less than table value at both levels which means it is not significant at both levels. Value of co-efficient correlation ' $r$ ' between Empowerment among urban adolescent girls and School Environment dimension of Cognitive Encouragement is -0.07 . The Table Value at 0.05 level is 0.19 and at 0.01 level is 0.25 . The calculated value is less than table value at both levels which means it is not significant at both levels. Value of co-efficient correlation ' $\mathrm{r}$ ' between Empowerment among urban adolescent girls and School Environment dimension of Acceptance is 0.14 . The Table Value at 0.05 level is 0.19 and at 0.01 level is 0.25.The calculated value is less than table value at both levels which means it is not significant at both levels. Value of coefficient correlation ' $r$ ' between Empowerment among urban adolescent girls and School Environment dimension of Permissiveness is 0.09 . The Table Value at 0.05 level is 0.19 and at 0.01 level is 0.25 . The calculated value is less than table value at both levels which it is not significant at both levels. Value of co-efficient correlation ' $r$ ' between Empowerment among urban adolescent girls and School Environment dimension of Rejection is 0.01. The Table Value at 0.05 level is 0.19 and at 0.01 level is 0.25 . The calculated value is less than table value at both levels which means it is not significant at both levels. Values of co-efficient correlation ' $r$ ' between Empowerment among urban adolescent girls and School Environment dimension of Control is 0.30 . The Table Value at 0.05 level is 0.19 and at 0.01 level is 0.25 . The calculated value is greater than table value at both levels which means it is significant at both levels.

From the above it is clear that obtained value of co-efficient of correlation is not significant at both 0.05 and 0.01 levels.

Therefore the hypothesis no.3 "There is no significant relationship between Empowerment and School Environment of Urban Adolescent girls" is accepted.

Objective 3: To compare the Empowerment level of Rural and Urban Adolescent girls.

Table 5:- Showing the significant difference between the Empowerment level of Rural and Urban Adolescent girls.

\begin{tabular}{|c|c|c|c|c|}
\hline \multicolumn{5}{|c|}{ Empowerment level among Adolescent Girls } \\
\hline Category & Mean & Standard Deviation & t-value & Interpretation \\
\hline Rural & 182.5 & 15.87 & \multirow{2}{*}{0.91} & \multirow{2}{*}{ Not Significan } \\
\hline Urban & 184.45 & 18.76 & & \\
\hline
\end{tabular}

Table 5 shows that Mean values of Empowerment level of Rural and Urban are 182.5 and 184.45 respectively. Standard Deviation of Empowerment level of Rural and Urban are 15.87 and 18.76 respectively. The t-value between the mean score of Empowerment level of Rural and Urban is found to be 0.91 . The Table Value at 0.05 level is 1.97 and at 0.01 level is 2.60 . The calculated value is less than table at both levels which means it is not significant at both 0.05 and 0.01 levels.

\section{Conclusions:-}

In the light of analysis and interpretation of data the following conclusions were drawn from sample taken in the present study:

- It is concluded that the co-efficient correlation ' $r$ ' is not significant for the relationship between Empowerment and School Environment of Rural Adolescent girls. So hypothesis no.2 "There is no significant relationship between Empowerment and School Environment of Rural Adolescent girls" is accepted.

- A careful examination of results revealed that co-efficient correlation is not significant for the relationship between Empowerment and School Environment of Urban Adolescent girls. So hypothesis no.3 "There is no significant relationship between Empowerment and School Environment of Urban Adolescent girls" is accepted. 
- A careful examination of results revealed no significant difference between mean scores of Empowerment among Rural and Urban Adolescent girls. So the hypothesis no.1 "There is no significant difference between the Empowerment level of Rural and Urban Adolescent girls" is accepted.

\section{Educational Implications:-}

* The teachers, parents and guidance workers can play on important role in the nourishment of all round development of school environment. The teacher should make new strategies to develop empowerment among adolescent girls which is helpful for increasing empowerment of adolescent girls.

* School environment affects the empowerment of adolescent girls.

* The present study tells us that how these two variables are important in life of adolescent girls. These help in their better adjustment.

* The present study is also helpful for parents to perform their duties towards their children properly. The dealing of parents with their children should be co-operative and friendly. In such an environment, the children will maintain their good and sound health; and empowerment of adolescents also increase in such an environment.

* Development of the school environment is one of the important aims of education. Therefore teachers, educators should put maximum efforts for the development of school environment of the girls by providing them enrichment programmes and remedial measures respectively. School environment is to process good social skills and communication skills.

* Hence a lot of opportunities should be provided in the curriculum to the girl students so that they can develop themselves fully.

* Adolescent girls, especially belonging to lower strata of society, can be made more aware and made to realize their being an integral part of society.

* The study aspires to change the mental set-up of the people towards adolescent girls.

\section{References:-}

1. Anand Aruna \& Kaur Malkeet (2014). Study of Relationship among Leadership Effectiveness School Environment and School Satisfaction of Adolescents, Education Sector, Registered and Referred Quarterly Research Journal, 4, Year :2, ISSN 232-0478, 52-57.

2. Basin Kamala (1992). Education for women's empowerment; Some refractions, Adult Educational Development, March, Number-88.

3. Chadna Nidhi \& Kaur Charanjit (2014). Achievement Motivation of students studying in smart and conventional schools in relation to school environment, Education Sector, Registered and Referred Quarterly Research Journal, I, Year 2, 18-23.

4. Daleta Vivek, Ahmad Sarfaraz (2012). Impact of Attitude towards the School Environment on the Academic Achievement of Adolescent, Quest- The Journal of UGC-ASC National, Quest Inter-disciplinary journal, 6, Issue.3, November 2012.

5. Gohlan Neeraj, Khurana Veenu (2013). Empowerment of adolescent girls in relation to their socio-economic status, Psycho Lingua, A Half yearly Research Journal,43(2), (ISSN : 0377-3132), 189-192.

6. Good (1945). Dictionary of Education, MC Grow Hill Book Company.

7. Good, C.V. (1959). Dictionary of Education, MC Grow Hill Book Company.

8. Goswami Marami (2013). Some correlates of women empowerment an analysis, Edu. Track, 12 (8).

9. Joshi Anita (2012). NGOs in the kumaon region as a means of women Empowerment: A study, Quest The Journal of UGC-ASC Nainital, Quest disciplinary Journal, 6, Issue 3.

10. Khatoon Mubina Syeda, Konwar, L.N. (2016). School climate perceived by the pupils and its relation to their Academic Achievement, Edu. Tracks, 13 (7), ISSN : 0972-9844, 36-40.

11. Leogermaa, P.M., Wallace, R.A. (1985). Gender in America social control and social change, Englewood Cliffs, N.J. Prentice Hall.

12. Lindelow, J (1989). School Climate Origen, ERIC learning house of ERIC and other Educational Management. ERIC Publications.

13. M. Craynest (2009). The contribution of home, neighborhood and school environment factor in explaining physical activity among adolescents, Journal of Environmental and Public Health, Article I.D 320372.

14. Modankar, R.R. (2013). Effect of personality, home environment and school environment on academic achievement among secondary school students, Edu. Tracks, 13(2), 32-37.

15. Sharma Rachna (2014). A study of self concept and empowerment of adolescent girls, Asian Journal of Multidisciplinary studies , 2, Issue 1, 109-113.

16. Sindhuja, T. Sreedevi, V. (2011). Self Help groups and women's empowerment, Journal of Community Guidance \& Research, 28 (2), 206-212.

17. Sweeney, J. (1988). Tips for improving School Climate, Arlington, American, Association of School Environment. 